\author{
Седікова I.O. \\ доктор економічних наук, доцент \\ E-mail: irina-sedikova@rambler.ru \\ Петрочко Н. А. \\ магістрант \\ кафедра менеджменту та логістики \\ Одеська національна академія харчових технологій \\ вул. Канатна, 112, м. Одеса, Україна, 65039 \\ E-mail: petrochko@mail.ua
}

\title{
ДОСЛІДЖЕННЯ НАПРЯМІВ ВПРОВАДЖЕННЯ СТРАТЕГІЇ ДИВЕРСИФІКАЦІЇ НА ПІДПРИЄМСТВАХ ВИНОРОБНОЇ ГАЛУЗІ
}

В роботі проведено системне дослідження напрямів впровадження стратегії диверсифікації та комплексу заходів щодо впровадження даної стратегії на підприємствах виноробної галузі, а також ії ефрективного використання для забезпечення конкурентоспроможності підприємства. Здійснено комплексний аналіз стратегії ТОВ «ПТК Шабо» та виявленні напрями розвитку стратегії диверсифікації. Проведено: аналіз конкурентоспроможності підприємства (карти стратегічних груп конкурентів за параметрами: широта асортименту - ціна та обсяги виробництва - якість; багатокутник конкурентоспроможності); здійснено портфельний аналіз підприємства за допомогою матриць БКГ та Мак-Кінсі; розроблено SPACE-аналіз та визначення стратегії підприємства.

Ключові слова: стратегія, стратегія диверсифікації, підприємства виноробної галузі, портфельний аналіз.

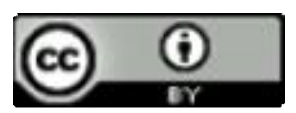

This work is licensed under a Creative Commons Attribution 4.0 International License http://creativecommons.org/licenses/by/4.0/
Постановка проблеми та її зв'язок з важливими науковими та практичними завданнями. Сучасний етап розвитку економіки України характеризується докорінною зміною умов функціонування організації, що обумовлюється підвищенням рівня мобільності зовнішніх чинників та посиленням їх впливу на внутрішнє середовище. За таких умов стає неможливим управляти, реагуючи на проблеми, що вже виникли, використовуючи наявний досвід або його екстраполяції. Це свідчить про необхідність наукового обгрунтування переходу до стратегічного управління, яке має передбачати не лише розробку альтернативних варіантів стратегії розвитку підприємства, вибір найбільш оптимального $з$ них, його послідовну реалізацію, але й докорінну перебудову системи управління, 3 метою підвищення іiі гнучкості та адаптивності до змін у зовнішньому середовищі, сприйнятливості до нововведень; максимальне використання інтелектуального потенціалу управлінського персоналу, техніки і технології управління; постійне впровадження заходів щодо самовдосконалювання та саморозвитку системи управління [1, с. 62].

В умовах ринкових відносин підприємства мають можливість самостійно формувати свою стратегію. Зараз стратегія розглядається як об'єднана система організації всієї роботи фірми і являє собою один 3 найважливіших елементів організації діяльності підприємства. Чітке визначення стратегії підприємства, а також іiї реалізація і контроль над її вико- нанням допомагає отримувати хороші результати своєї діяльності

Аналіз останніх публікацій по проблемі. Теоретичні та практичні аспекти стратегічного управління підприємствами знайшли відображення в наукових роботах закордонних та вітчизняних вчених: I. Ансоффа, А. Чандлера, Р. Акоффа, М. Портера, А. Дж. Стрікленда, А. Томпсона, Ф. Котлера, О. Віханського, О. Градова, Р. Фатхутдінова, М. Круглова, П. Забєліна, Н. Моїсєєвої, І. Бланка, Н. Мартиненко, Ю. Іванова, М. Виноградського, О. Седікової І., З. Шершньової та ін. Переважно їхні роботи пов'язані 3 управлінням великими багатопрофільними компаніями, корпораціями, концернами. Існуючі наукові підходи щодо розробки стратегії підприємств носять загальний характер, що обмежує сферу їхнього застосування через специфічні галузеві особливості. Виникає необхідність вирішення теоретичних i методичних питань, пов'язаних з розкриттям суті поняття стратегії розвитку, розробкою алгоритму формування стратегії розвитку вітчизняних виноробних підприємств, моделі формування стратегії розвитку з урахуванням специфіки об'єкту дослідження та можливих сценаріїв майбутнього. Актуальність цих питань зумовили вибір теми даного дослідження, його мету та завдання.

Формулювання цілей дослідження. Метою даного дослідження є дослідження напрямів впрова- 
дження стратегії диверсифікації на підприємствах виноробної галузі.

Виклад основних результатів та їх обгрунтування. До провідних галузей економіки України, які мають перспективи виходу на світовий ринок, традиційно відносять виноградарсько-виноробне виробництво. Його основні види продукції: вино, шампанське, коньяк - за своїми споживчими властивостями є унікальними і затребуваними як на внутрішньому, так і на зовнішньому ринках [4, с. 18]. Виноградарство України у зв'язку з останніми політичними подіями зазначило значні втрати площ виноградників. Після анексії Криму загальна площа українських виноградників зменшилась 375,1 тис. га до 48, 7 тис. га у 2014 році. Нажаль виноградарство займає невелику частку при виробництві валової продукції сільського господарства України - у 2014 р. частка виноградарства складала лише $0,3 \%$, а у продукції рослинництва $-0,55 \%$. Велику значимість тут відіграє зональне розташування та концентрація виробництва винограду. Наприклад, в Одеській області така частка складає $5,4 \%$ та 6,6\%, у Миколаївській області - 1,3 і 1,7 \%, Херсонській - 1,2 і 1,6 \% відповідно. Натомість, частка виноградарства сільськогосподарських підприємств у прибутках є значно вищою - так по Україні вона складає 0,7 \%, в Одеській області - 3,3 \%, у Миколаївській області - 5,3\%, у Херсонській - 5,4 \%, [5, c. 39]. У 2012 та 2013 рр. біля s українського винограду (відповідно 71,2 і 73,9 \%) були використані у процесі переробки на виноматеріали. У 2014 р. частка виноматеріалу, що переробляється, суттєво зменшилась до 52,3 \%, а обсяги виробництва скоротилися майже вдвічі - до 6062 тис. дал. За результатами проведеного моніторингу ринку встановлено, що виробництво ігристого вина у 2016 р. порівняно із 2015 р. збільшилось на 64,1 дал (3 \%), тихих вин - зменшилось на 38 дал. (1\%) та коньяку - зменшилось на 213,8 дал. (14\%).

Основні виробники ігристих вин в Україні: Основні виробники ігристих вин в Україні: ТОВ «ПТК «Шабо»», ПрАТ «Ізмаїльський виноробний завод», ТОВ «Вин-Агро», ЗАТ «Одеський завод шампанських вин», ПрАТ «Шустов», ЗАТ «Киівський завод шампанських вин «Столичний»», ПрАТ «Одесавинпром», ПрАТ «Артемівськ вайнері», НВП «Нива» ТОВ та інші. Основні виробники тихих вин в Україні: ТОВ «ПТК «Шабо»», ТОВ «Агро-Дар», ПрАТ «Вікторія», ПрАТ «Одесавинпром», ПрАТ «Харчовик», ТОВ «Атлантіс», НПП «Нива» ТОВ, ПАТ «ДМК «Таврія», ПАТ «Коблево». Основні виробники коньяку в Україні: ТОВ «ПТК «Шабо»», ПАТ «ДМК «Таврія», ПрАТ «Шустов», орендне підприємство «Ужгородський коньячний завод», ТОВ «Миколаївський коньячний завод», «Аквавінтекс» СП, ТОВ та інші. Найбльшу частку по вироництві ігристих вин в Україні займає НВП «Нива» ТОВ, тихих вин - ПАТ «Коблево» та коньяку ТОВ «ПТК «Шабо»».

Найбільший об'єм експорту ігристого вина у 2015-2016 рр. припадає на Росію і становить 18,89 тис. дал. у 2016 р. та 26,37 тис. дал. у 2015 р. Що стосується тихих вин, то найбільша частка експорту припадає на Китай та становить 53,32 \% у 2016 р. та 52,69 \% у 2015 р. Щодо коньяку, то у 2016 р. найбільше експортується продукція в Азербайджан та становить 3,29 тис. дал., а у 2015 p - в Росію, що становить 120,7 тис. дал. або 93,15 \% всього експорту коньяку у 2015 р. Приріст імпорту виноробної продукції в України є позитивним по всіх позиціях. Так, протягом семи місяців 2016 р. в Україну було ввезено 155,5 тис. дал. ігристого вина, що на 46,70 \% більше порівняно $з$ аналогічним періодом 2015 р., тихих вин - 910 тис. дал., що на 298 тис. дал. більше порівняно з 2015 p. та коньяку - 133,4 тис. дал., на 41,16 \% більше за 2015 p. [7, c. 157]

Проведені розрахунки досліджуваних показників нестабільності середовища функціонування виноробних підприємств України засвідчили значну диференціацію ії рівнів. 38 досліджених показників 5 виявились не прогнозованими, що є ознакою стохастичних змін середовища. Разом 3 цим, прогнозованість 3 інших не слід вважити безальтернативно значимою ознакою прогнозованості змін у виноробстві України. Так, прогнозованість кількості зареєстрованих підприємств здебільшого обумовлено прогресуючою тенденцією збільшення кількості зареєстрованих підприємств, значна частина яких не стають діючими.

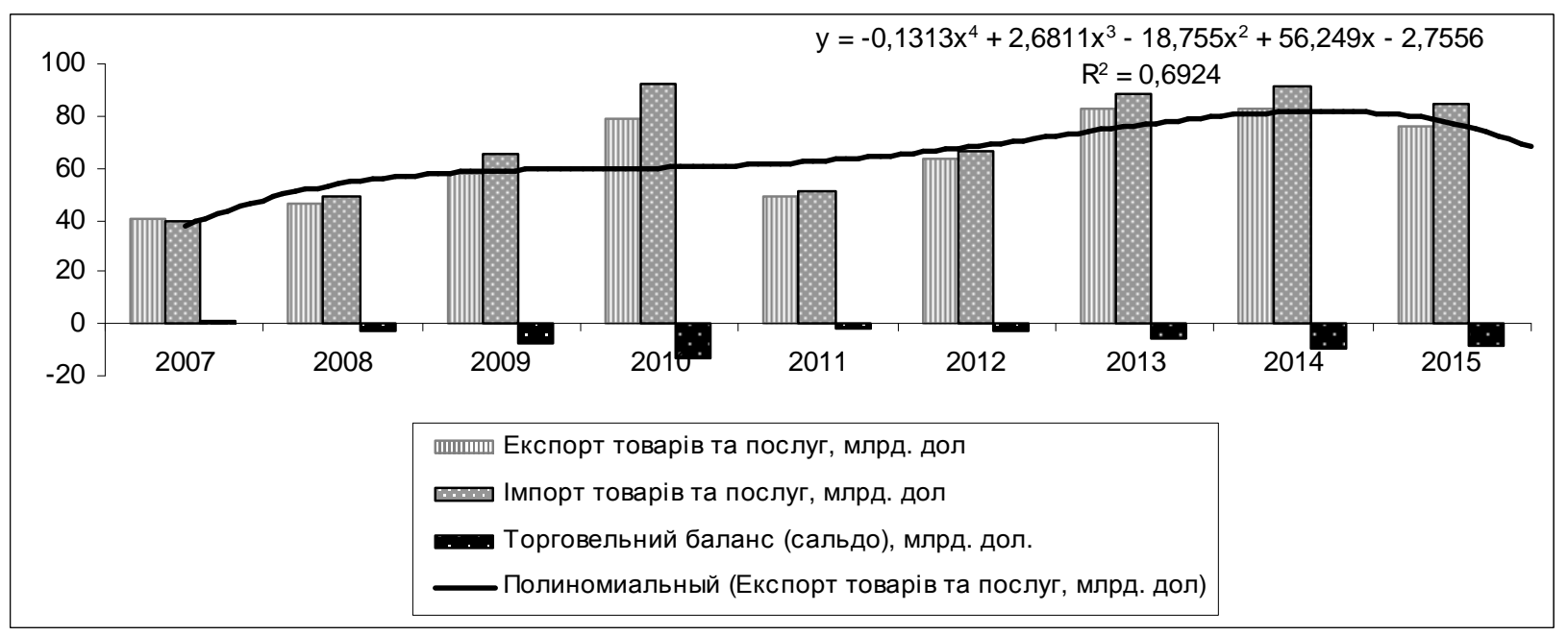

Рис. 1. Середовище функціонування виноробних підприсмств України [авторська розробка] 
Для аналізу конкурентного середовища ринку виноробної продукції та визначення конкурентних позицій на цьому ринку ТОВ «ПТК «Шабо»» проведено конкурентний аналіз. Для побудови карт стратегічних груп конкурентів підприємства ТОВ «ПТК «Шабо»» у сфері виробництва та продажу виноробної продукції візьмемо діяльність таких найбільших підприємств у даній галузі в Україні: ТОВ «ПТК Шабо», ПрАТ «Одесавинпром» (ТМ «Французький бульвар»), ПрАТ «Шустов» («Одеський коньячний завод»), ПАТ «Коблево», ПАТ «ДМК «Таврія», ПрАТ «Артемівськ вайнері», ТОВ «Вин-Агро», ПрАТ «Вікторія», Агрофірма радгосп «Білозерський», ПрАТ «Ізмаїльський виноробний завод», ПАТ «Князя Трубецького», ТОВ «Миколаївський коньячний завод». Побудовано дві карти стратегічних груп конкурентів. Для першої карти стратегічних груп конкурентів буди обрані параметри широта асортименту та ціна, для другої - обсяги виробництва-якість. За результатами аналізу підприємства було згруповані у три групи:

I група (з параметрами - широкий асортимент та висока чи середня ціна): ТОВ «ПТК Шабо», ПрАТ «Одесавинпром», ПрАТ «Шустов», ПАТ «Коблево», ПАТ «ДМК «Таврія»».

II група (з параметрами: середній асортимент та низька ціна): ПрАТ «Вікторія», Агрофірма «Білозерський», ПрАТ «Артемівськ вайнері» та ТОВ «Миколаївський коньячний завод».
III група (з параметрами: середній асортимент та висока ціна) в: ТОВ «Вин-Агро», ПрАТ «Ізмаїльський виноробний завод» та ТОВ «Миколаївський коньячний завод».

Проаналізувавши ринок виноробної продукції можна зробити висновок, що він є досить привабливим і перспективним. На ринку діє жорстка конкуренція і боротьба за споживача, тому слід проаналізувати рівень конкурентоспроможності виноробної продукції нашого підприємства і підвищити його для того, щоб збільшити свою долю на ринку та зайняти кращу позицію. Проаналізуємо основні характеристики продукції та діяльності підприємства в цілому, що впливають на рівень іiі конкурентоспроможності і порівняємо їх з характеристиками продукції та діяльності основних конкурентів. Для аналізу були обрані такі характеристики продукції як: обсяги реалізації, частка ринку, якість, ціна, широта асортименту, рівень впізнання споживачами торгової марки, унікальність власних технологій, доступність покупки продукції. Для аналізу конкурентоспроможності обраних підприємств була використана п'ятибальна система оцінки (від 1 до 5). 3 табл. 1 ми бачимо, що TOB «ПТК Шабо» займає перше місце 3 п'яти запропонованих підприємств, ділячи його з ПрАТ «Одесавинпром» і має середню оцінку за всіма критеріями 4,75 бали з 5-ти можливих.

Таблиця 1

Оцінювання підприємств (в балах)*

\begin{tabular}{|c|c|c|c|c|c|}
\hline Заклад / Критерій & 点 & 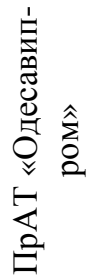 & 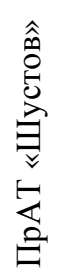 & 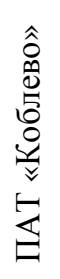 & 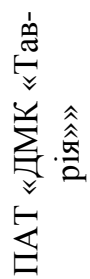 \\
\hline Обсяги реалізації (2016 р.) & 4 & 5 & 3 & 4 & 5 \\
\hline Частка ринку, \% & 5 & 4 & 4 & 3 & 5 \\
\hline Якість & 5 & 5 & 5 & 5 & 5 \\
\hline Ціна (середня ціна на коньяк $\left.5^{*}, 0,5 л\right)$, грн. & 4 & 5 & 5 & 4 & 3 \\
\hline Широта асортименту & 5 & 4 & 3 & 3 & 4 \\
\hline Рівень впізнання споживачами торгової марки & 5 & 5 & 5 & 4 & 4 \\
\hline Унікальність власних технологій & 5 & 5 & 5 & 5 & 5 \\
\hline Доступність покупки продукції & 5 & 5 & 5 & 4 & 5 \\
\hline Всього & 38 & 38 & 35 & 32 & 36 \\
\hline
\end{tabular}

* авторська розробка

Провівши портфельний аналіз за допомогою матриці БКГ нами виділено такі стратегічні зони господарства як група виробництва виноробної продукції, група - ігристих вин, група - тихих вин та група коньяків. В ході аналізу ми визначили, що СЗГ2 попали в зону «собаки», яка характеризується відносно низькою часткою ринку і низькими темпами росту, так як цей елемент займає ПрАТ «Одесавинпром» при невеликих темпах росту. Рекомендується провести перегляд асортиментної політики по даний СЗГ, але не ліквідувати іiі для збереження широти асортименту. СЗГ1 попала в зону «дикі кішки», вона має незначну частку на ринку, яка швидко розвивається, тому рекомендується вкладати кошти в даний бізнес для покращення його позиції на ринку і переводу в зону «зірки». СЗГЗ попала в зону «дійні корови», яка характеризується тим що товари активно реалізуються на ринку і дають фірмі суттєві прибутки. Вони не потребують значних інвестицій, тому що методика їх виробництва налагоджена і витрати виробництва та 
збуту мінімальні. Прибутки від продажу цієї групи товарів ідуть на фінансування інших товарних груп. Рекомендується прийняти стратегію «утримання»; підтримувати лідируюче положення на ринку; провести інвестування в модернізацію виробів; підтримати лідируюче положення за ціною; використовувати частину прибутку для підтримки продуктів категорії «важкі діти» $\mathrm{i}$ «зірки»[8].

Провівши аналіз за допомогою матриці Мак Кінсі, у процесі аналізу було виявлено, зо СЗГ 2 попала в зону, яка характеризується низькою конкурентною позицією і низькою привабливістю галузі і рекомендується даний бізнес скорочувати. СЗГЗ характеризується середнім пріоритетом для інвестицій для них рекомендується здійснювати інвестиції на попередньому рівні $з$ метою збереження і захисту своїх позицій. СЗГ1 знаходиться у зоні з най вищим пріоритетом для інвестицій, об'єм в даний бізнес слід збільшувати.

Для того щоб визначити, яка існує на даний момент стратегія на підприємстві скористуємося
SPACE-аналізом. Для оцінки фінансової сили підприємства було обрано показники рентабельності інвестицій, динаміки прибутку та рівня фінансової стійкості (залежності від зовнішніх зобов'язань). Результати зваженої оцінки фінансової сили підприємства $(4,3$ бала) свідчать про наявність певних проблем на підприємстві, пов'язаних із забезпеченням ефективного використання вкладеного капіталу.

Так само невисоким є і рівень конкурентоспроможності підприємства (5,8 бала) через незнання керівництвом підприємства секрету доходності бізнесу, про достатньо високий рівень якого свідчать високі оцінки привабливості та стабільності галузі $(6,5$ бала та 6,6 бала відповідно). На основі вивчення ключових критеріїв у складі кожної групи складено матрицю спрямованої стратегії в системі координат SPACE та побудовано вектор позиції підприємства, що оцінюється. Положення вектора визначає тип рекомендованої стратегії (консервативна, захисна, конкурентна, агресивна) для зміцнення конкурентних позицій.

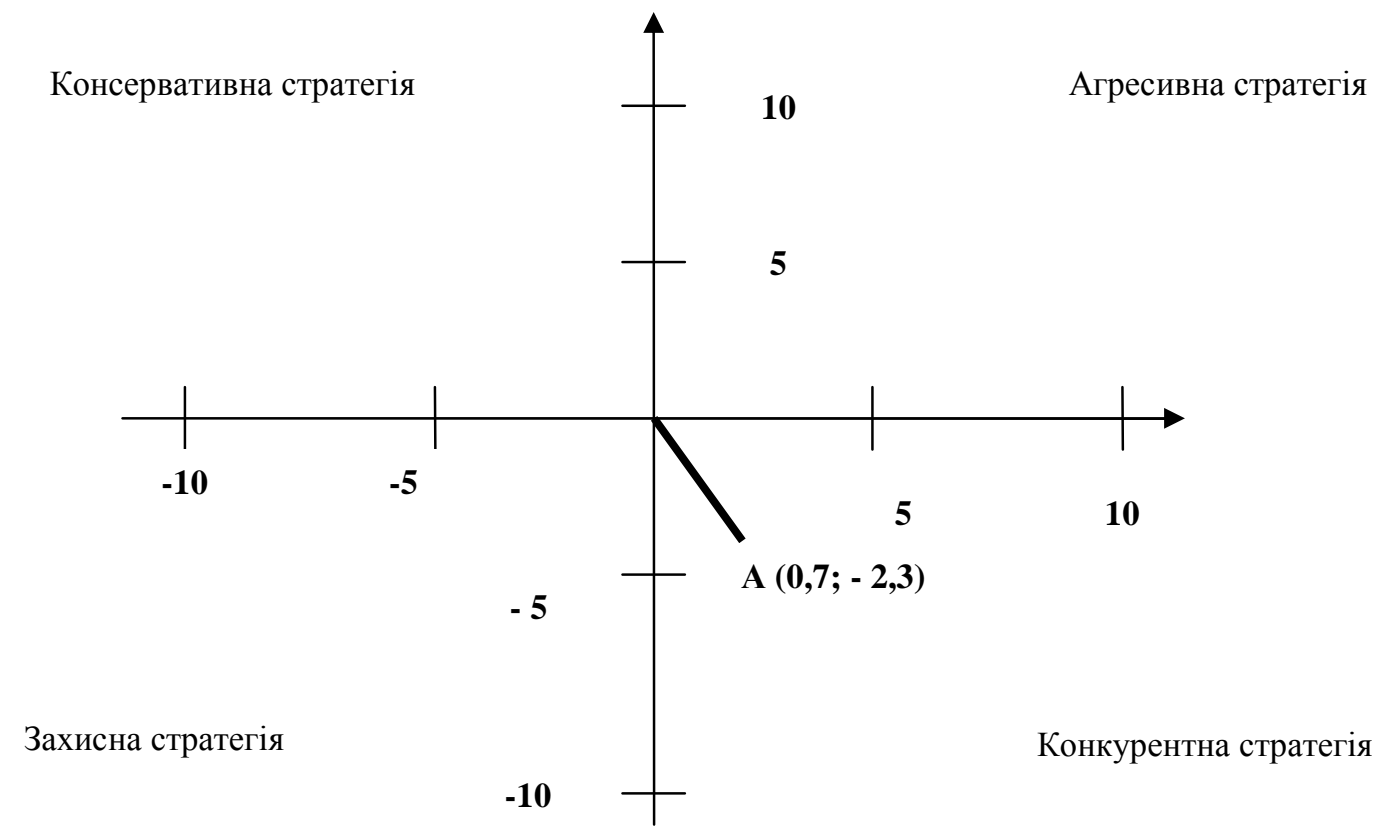

Рис. 2. Визначення вектора рекомендованої стратеги підприємства в системі координат SPACE [авторська розробка]

Отже, підприємству ТОВ «ПТК Шабо» характерна конкурентна стратегію. Дана стратегія характерна для привабливої галузі. Організація отримує конкурентні переваги у відносно нестабільній обстановці. Критичним фактором $є$ фінансовий потенціал. Необхідно парирувати погрози, пов'язані 3 втратою фінансування. Основні механізми - це пошук фінансових ресурсів та розвиток збутових мереж.

Висновки та перспективи подальших досліджень. Проаналізувавши конкурентне середовище та проведення портфельного аналізу підприємства ТОВ «ПТК Шабо» буде доцільно рекомендувати компанії змінити стратегію іiі діяльності на стратегію диверсифікації та впровадити новий винний тур, який б стосувався суто ігристих вин, адже на даний момент компанія вже запровадила «Дім ігристих вин Shabo». На основі стратегічного аналізу діяльності ТОВ «ПТК Шабо», можна стверджувати, ефективною стратегією, яка відповідатиме внутрішнім параметрам компанії та iï положенню на ринку являється стратегія диверси- 
фікації, заснована на використанні сильних сторін компанії в поєднанні із зовнішніми можливостями.

За результатами проведеного дослідження компанія ТОВ «ПТК Шабо» має перспективні структурні бізнес одиниці. Специфіка компанії полягає у тому, що найменший обсяг випущеної продукції припадає на ігристе вино, чим пояснюється нестійка тенденція в секторі даної продукції, адже ії доля в загальному обсязі не дуже значна. Відповідно компанії потрібно використовувати агресивну стратегію для завоювання потенційних споживачів. Тому буде доцільно зарекомендувати компанії змінити стратегію іiі діяльності на стратегію диверсифікації та впровадити новий винний тур, який б стосувався суто ігристих вин, адже на даний момент компанія вже запровадила «Дім ігристих вин Shabo». А це у свою чергу дозволить ТОВ «ПТК Шабо» не лише збільшити продажі своєї продукції та частку на ринку, а й збільшить прибутки за рахунок нового напрямку діяльності туризму.

\section{Література}

1. Авидзба А. М. Программа развития виноделия в Украине до 2025 года и пути ее реализации / А. Авидзба // ВиноГрад. - 2009. - №№ -7-8. - С. 61-63.

2. Клівець П.Г. Стратегія підприємства: [навч. посіб.] / П.Г. Клівець. - К.: Академвидав, 2007. - 320 с.

3. Трояновська О.Б. Конспект лекцій 3 курсу «Стратегія підприємства» / О.Б. Трояновська. - Х.: ХНАМГ, 2012. - $121 \mathrm{c.}$

4. Артеменко Л. П. Стратегічний розвиток підприємств в умовах турбулентності середовища (п.1.1); Концепція забезпечення економічної безпеки стратегічного розвитку підприємства (п.1.3); Методичні засади оцінювання рівня конкурентоспроможності машинобудівних підприємств на основі конкурентного потенціалу (п.4.4): [монографія] / Л.П. Артеменко // Конкурентні домінанти стратегічного розвитку підприємств / [Дергачова В.В., Сімченко Н.О., Бояринова К.О. та ін.]. - Черкаси: Видавець Чабаненко Ю.А., 2013. - С.13-37, 67 - 77, 353-376.

5. Баланси та споживання основних продуктів харчування населенням України: статистичний збірник / Державна служба статистики України. - К., 2013. - С. 39.

6. Бараненко С. П. Стратегический менеджмент: учебно-методический комплекс / С. П. Бараненко, М. Н. Дудин, Н. В. Лясников. - М.: ЗАО «Центрполиграф», 2010. - 319 с.

7. Баюра Д.О. Теоретичні аспекти розвитку стратегічного планування на підприємствах в умовах ринкової нестабільності / Д.О. Баюра, В.В. Петрук. - Наукові праці НДФІ. - К.: 2014. - С.153-158.

8. Винная дорога Одещины / [Власов В. В., Джабурия Л.В., Белоус И.В. и др.] // ВиноГрад. - 2015. №2. - C. 37-40.

9. Гаркуша О. М. Стратегія відновлення і високоефективного функціонування виноградарськовиноробного підкомплексу АПК України в умовах ринкової економіки : дис. докт. ек. наук : 08.07.02 / Гаркуша О. М. - Миколаїв, 2002. - 370 с.

10. Дрінь О. Я. Поліформізм стратегій підприємства в диференційованих умовах організаційного середовища / О. Я. Дрінь, І. В. Смолін // Стратегія економічного розвитку України: зб. наук. праць КНЕУ ім. Вадима Гетьмана. - 2012. - № 31. - С. 3-10.

Стаття надійшла 08.02.2017

Стаття прийнята до друку 22.03.2017

Доступно в мережі Internet 31.03.2017

Седикова И.А.

доктор экономических наук, доцент

E-mail: irina-sedikova@rambler.ru

Петрочко Н.A.

магистрант

кафедра менеджмента и логистики

Одесская национальная академия пищевых технологий

ул. Канатная, 112, г. Одесса, Украина, 65039

E-mail:petrochko@mail.ua

\section{ИССЛЕДОВАНИЕ НАПРАВЛЕНИЙ ВНЕДРЕНИЯ СТРАТЕГИИ ДИВЕРСИФИКАЦИИ НА ПРЕДПРИЯТИЯХ ВИНОДЕЛЬЧЕСКОЙ ОТРАСЛИ}

Доказано, что в рыночных условиях ведения бизнеса предприятия самостоятельно формирують свою стратегиюразвития. Установлено, что существующие научные подходы к разработке стратегии предприятий носят общий характер, ограничивающий сферу их применения из-за отраслевой 
специфики. В данной статье, проанализировано современное состояние и тенденции развития винодельческой отрасли Украины, основной асортимент, віппускаемой продукции. Шампанское, коньяк по своим потребительским свойствам являются уникальными и востребованными как на внутреннем, так и на внешнем рынках. Определены основные производители винодельческой продукции Украины. Проведены расчеты показателей нестабильности внешней среды функционирования винодельческих предприятий Украины, которые показали значительную дифференциацию ее уровней.

Проанализирована конкурентная среда рынка винодельческой продукции и определені конкурентные позиций компании ООО «ПТК Шабо»». Построены карты стратегических групп конкурентов предприятия в сфере производства и продажи винодельческой продукции. Построены карты стратегических групп конкурентов. Для первой карты стратегических групп конкурентов избраны параметры: широта ассортимента и цена, для второй - объемы производства и качество. Проанализировав рынок винодельческой продукции, сделан вывод о его перспективности и привлекательности для инвесторов. Проанализированы основные характеристики продукции и деятельности предприятия, влияющие на уровень его конкурентоспособности в сравнении с основними конкурентами. С помощью матрицы БКГ проведен портфельный анализ и обозначены стратегические зоны хозяйствования. На основе изучения ключевых критериев, в составе каждой группы, построена матрица направленной стратегии в системе координат SPACE и определен вектор стратеги развития ООО «ПТК Шабо»». Проанализировав конкурентную среду и проведя портфельного анализ ООО «ПТК Шабо», компании рекомендовано, для укрепления своих позиций и расширения сферы деятельности применить стратегию диверсификации и разработать новый винный тур, с дегустацией игристых вин.

Ключевые слова: стратегия, стратегия диверсификации, предприятия винодельческой отрасли, портфельный аналіз.

\author{
Sedikova I. \\ Doctor of Economics, Associate Professor \\ E-mail: irina-sedikova@rambler.ru \\ Petrochko N. \\ Undergraduate \\ Department of Management and Logistics \\ Odessa National Academy of Food Technologies \\ Kanatna str., 112, Odessa, Ukraine, 65039 \\ E-mail: petrochko@mail.ua
}

\title{
RESEARCH AREAS OF IMPLEMENTATION OF THE STRATEGY OF DIVERSIFICATION IN THE WINE INDUSTRY ENTERPRISES
}

It is proved that in the market conditions enterprises are allowed to shape their strategy. It is indicated that the existing scientific approaches to develop business strategies are general in nature, limiting the scope of their application through industry-specific features.

The current state and trends in the wine industry in Ukraine were analyzed. Its main products are: wine, champagne, cognac - in its consumer properties are unique and are in demand both in domestic and foreign markets. The main producers of wine products in Ukraine were identified. The calculations of volatilities indices of operation environment concerning wineries in Ukraine, have been fulfilled which showed significant differentiation of levels.

The competitive landscape of the market wine products and the definition of the competitive position of LLC «PTK Shabo» on the market were analyzed. Maps of strategic groups of competing businesses in the production and sale of wine were constructed. Two maps of strategic groups of competitors were created. For the first map of strategic groups of competitors the next options were chosen: breadth of assortment and price and for the second - output and quality. After analyzing the market of wine products a conclusion was made about its attractiveness and prospects. The basic characteristics of the product and the enterprise as a whole, affecting the level of competitiveness, were analyzed, and they were compared to the characteristics of products and key competitors. Having made portfolio analysis using BCG matrix strategic areas of management was selected. On the basis of key criteria in the composition of each group a matrix of strategies in the SPACE coordinate system and LLC «PTK Shabo» vector of development position of the company, were constructed. 
After analyzing the competitive landscape and analysis of portfolio of LLC «PTK Shabo» company, it was recommended to change the strategy of its activity in diversification strategy and to introduce a new wine tour, which would deal with strictly sparkling wines, because at the moment the company is introducing a «House of Shabo sparkling wines». The information is based on a strategic analysis of LLC «PTK Shabo».

Keywords: strategy, diversification, enterprise wine industry, portfolio analysis.

\section{References}

1. Avydzba, A. M. (2009). Prohramma razvytyia vynodelyia v Ukrayne do 2025 hoda y puty ee realyzatsyy . VynoHrad, 7-8, 61-63.

2. Klivets , P. H. (2007). Stratehiia pidpryiemstva. K.: Akademvydav.

3. Troianovska , O. B. (2012). Konspekt lektsii z kursu «Stratehiia pidpryiemstva». Kh.: KhNAMH.

4. Artemenko , L. P. (2013). Stratehichnyi rozvytok pidpryiemstv v umovakh turbulentnosti seredovyshcha . Cherkasy: Chabanenko Iu.A.

5. Balansy ta spozhyvannia osnovnykh produktiv kharchuvannia naselenniam Ukrainy: stat ystychnyi zbirnyk. (2013). K.: Derzhavna sluzhba statystyky Ukrainy.

6. Baranenko, S. P., Dudyn, M. N., \& Liasnykov, N. V. (2010). Stratehycheskyi menedzhment: uchebnometodycheskyi kompleks . M.: ZAO «Tsentrpolyhraf».

7. Baiura , D. O., \& Petruk, V. V. (2014). Teoretychni aspekty rozvytku stratehichnoho planuvannia na pidpryiemstvakh v umovakh rynkovoi nestabilnosti . K.: Naukovi pratsi NDFI.

8. Vlasov, V. V., Dzhaburyia, L. V., \& Belous, Y. V. (2015). Vynnaia doroha Odeshchynы. VynoHrad, 2, $37-40$.

9. Vlasov, V. V., Dzhaburyia, L. V., \& Belous, Y. V. (2015). Vynnaia doroha Odeshchynы. VynoHrad, 2, 37-40.

10. Drin , O. I., \& Smolin, I. V. (2012). Poliformizm stratehii pidpryiemstva v dyferentsiiovanykh umovakh orhanizatsiinoho seredovyshcha. Stratehiia ekonomichnoho rozvytku Ukrainy, 31, 3-10.

Received 08 February 2017

Approved 22 February 2017

Available in Internet 31.03.2017 